\title{
Constraints to Pearl Millet (Pennisetum glaucum) Production and Farmers' Approaches to Striga hermonthica Management in Burkina Faso
}

\author{
Armel Rouamba ${ }^{1,2} \mathbb{D}^{\mathbb{D}}$, Hussein Shimelis ${ }^{1}\left(\mathbb{D}\right.$, Inoussa Drabo ${ }^{2}$, Mark Laing ${ }^{1}$, , Prakash Gangashetty ${ }^{3}(\mathbb{D}$, \\ Isack Mathew ${ }^{1}$ D , Emmanuel Mrema ${ }^{4}$ and Admire Isaac Tichafa Shayanowako ${ }^{1, *}$ \\ 1 African Centre for Crop Improvement, School of Agricultural, Earth and Environmental Sciences, \\ University of KwaZulu-Natal, Pietermaritzburg Private Bag X01, Scottsville 3209, South Africa; \\ armelrouamba@yahoo.fr (A.R.); Shimelish@ukzn.ac.za (H.S.); laing@ukzn.ac.za (M.L.); \\ isackmathew@gmail.com (I.M.) \\ 2 Institute of Environmental and Agriculture Research, Ouagadougou 01 BP 476, Burkina Faso; \\ draboinos@yahoo.fr \\ 3 International Crop Research Institute for Semi-Arid Tropics (ICRISAT), Hyderabad 502 324, India; \\ P.Gangashetty@cgiar.org \\ 4 Tumbi Agriculture Research Institute, P.O. Box 306, Tabora, Tanzania; mremaemmanuel@yahoo.com \\ * Correspondence: shayanowako@gmail.com
}

check for updates

Citation: Rouamba, A.; Shimelis, H.; Drabo, I.; Laing, M.; Gangashetty, P.;

Mathew, I.; Mrema, E.; Shayanowako, A.I.T. Constraints to Pearl Millet

(Pennisetum glaucum) Production and Farmers' Approaches to Striga hermonthica Management in Burkina Faso. Sustainability 2021, 13, 8460. https://doi.org/10.3390/ su13158460

Academic Editor: Markus Keck

Received: 3 June 2021

Accepted: 11 July 2021

Published: 29 July 2021

Publisher's Note: MDPI stays neutral with regard to jurisdictional claims in published maps and institutional affiliations.

Copyright: (c) 2021 by the authors. Licensee MDPI, Basel, Switzerland. This article is an open access article distributed under the terms and conditions of the Creative Commons Attribution (CC BY) license (https:// creativecommons.org/licenses/by/ $4.0 /)$.
Abstract: Pearl millet (Pennisetum glaucum) is a staple food crop in Burkina Faso that is widely grown in the Sahelian and Sudano-Sahelian zones, characterised by poor soil conditions and erratic rainfall, and high temperatures. The objective of this study was to document farmers' perceptions of the prevailing constraints affecting pearl millet production and related approaches to manage the parasitic weeds S. hermonthica. The study was conducted in the Sahel, Sudano-Sahelian zones in the North, North Central, West Central, Central Plateau, and South Central of Burkina Faso. Data were collected through a structured questionnaire and focus group discussions involving 492 participant farmers. Recurrent drought, S. hermonthica infestation, shortage of labour, lack of fertilisers, lack of cash, and the use of low-yielding varieties were the main challenges hindering pearl millet production in the study areas. The majority of the respondents (40\%) ranked S. hermonthica infestation as the primary constraint affecting pearl millet production. Respondent farmers reported yield losses of up to $80 \%$ due to $S$. hermonthica infestation. $61.4 \%$ of the respondents in the study areas had achieved a mean pearl millet yields of $<1 \mathrm{t} /$ ha. Poor access and the high cost of introduced seed, and a lack of farmers preferred traits in the existing introduced pearl millet varieties were the main reasons for their low adoption, as reported by $32 \%$ of respondents. S. hermonthica management options in pearl millet production fields included moisture conservation using terraces, manual hoeing, hand weeding, use of microplots locally referred to as 'zaï', crop rotation and mulching. These management techniques were ineffective because they do not suppress the below ground S. hermonthica seed, and they are difficult to implement. Integrated management practices employing breeding for S. hermonthica resistant varieties with the aforementioned control measures could offer a sustainable solution for S. hermonthica management and improved pearl millet productivity in Burkina Faso.

Keywords: agro-ecology; plant breeding; integrated pest management; pearl millet; production constraints; Striga hermonthica

\section{Introduction}

Pearl millet (Pennisetum glaucum [L.] R. Br., $2 n=2 x=14$ ) is the sixth most important cereal crop in the world after wheat, rice, maize, barley, and sorghum [1]. The crop is adapted to arid and semi-arid environments and grows relatively well under low soil fertility conditions, outperforming other common cereal crops such as maize and wheat [2]. Approximately 22 million hectares of land in Africa are under pearl millet production 
with mean productivity of 1 ton ha ${ }^{-1}$ [3]. In Burkina Faso, the mean yield under the smallholder production system is estimated at 0.85 tons ha $^{-1}$ compared to a potential yield of 3.00 tons ha ${ }^{-1}$ achievable under research conditions [3]. This yield gap can be attributed to biotic and abiotic constraints and socio-economic challenges. The key biotic constraints to pearl millet production are parasitic weeds (Striga species), bird damage, downy mildew, head miner, and the use of low-yielding landraces [4].

Drought stress and low soil fertility are among the major abiotic constraints affecting pearl millet production [4]. In Burkina Faso, pearl millet is mainly grown in the semiarid Sahelian and Sudano-Sahelian zones that are characterized by poor soils, low and erratic rainfall, and high temperatures. The intensity and frequency of biotic and abiotic stresses intensified by climate change have increased in sub-Saharan Africa (SSA), including Burkina Faso, which has increased the need for resilient crop cultivars [5].

Striga species are notorious parasitic weeds affecting pearl millet production in the Sahel and Sudano-Sahel regions [6]. There are 13 Striga species reported in Burkina Faso, with Striga hermonthica (Del.) Bentham and S. gesneroïdes (Willd) Vatke being the most devastating weeds of cereal and legume crops, respectively [7]. Yield losses due to S. hermonthica vary between 7 and $41 \%$ in the central zones, while up to $55 \%$ losses have been reported in the eastern zones of Burkina Faso [8,9]. The parasitic weed has a wide range of hosts, including rice (Oryza glaberrima Steudel and O. Sativa L.), maize (Zea mays L.), sorghum (Sorghum bicolour [L.] Moench), pearl millet, and fonio (Digitaria exilis (Kippist) Stapf) $[7,10]$. The wide host range, the easy dispersal of $S$. hermonthica seeds by animals and wind, and the seeds' ability to stay viable in the soil for about 14 years make it difficult to control the weed [6].

Farmers employ hand weeding, crop rotation, and botanicals such as a concoction powder prepared from pods of the African locust bean (Parkia biglobosa (Jacq.) R. Br. ex G. Don) and almonds of the shea tree (Vitellaria paradoxa C.F. Gaertn.) to control S. hermonthica [7]. These methods reduce the amount of $S$. hermonthica seed in the soil and improve soil fertility, but they have high labour requirements that limit their implementation and use. The use of chemical herbicides is not widely reported among smallholder farmers due to their high cost, limited access, and potential environmental hazards. In addition, the use of host plant resistance against $S$. hermonthica is limited by poor access to or the unavailability of resistant varieties. A combination of effective S. hermonthica control methods is required to reduce $S$. hermonthica on pearl millet production in SSA.

The active participation of farmers in developing strategies to control S. hermonthica is important to ensure high adoption of the developed strategies. It is also imperative to understand the important traits of a pearl millet variety that the farmers require to design and breed farmer-preferred pearl millet varieties. Participatory rural appraisal (PRA) is a multi-disciplinary research tool used to gain information from farmers through their participation in the initial stages of technology development. The tool helps to understand the farmers' knowledge, experiences, perceived and encountered production constraints, preferred traits, and their agricultural needs $[10,11]$. It emphasizes incorporating local knowledge in developing new interventions [12], which provides opportunities for local people to define their circumstances, conduct a situational analysis, and draft suitable plans for intervention. The PRA approach has been used to identify farmers' production constraints, preferred crop varieties, understand their agricultural environment, and develop suitable intervention strategies [13,14]. DeVries and Toenniessen [15] emphasized the need for farmers' involvement in all stages of cultivar development, including prioritizing target traits, selecting early breeding generations, and varietal evaluations to accommodate and promote their input in the breeding value chain.

Omanya et al. [16] lamented the low adoption rates of "improved" cultivars of pearl millet in Senegal, which was attributed to poor information dissemination among farmers and a disregard of farmers' opinions by the plant breeders during cultivar development. Farmers in Nigeria were involved in a PRA study and identified S. hermonthica infestation as the most important constraint of pearl millet production, and consequently, 
S. hermonthica resistance was the most preferred trait in pearl millet [17]. In Burkina Faso, PRA was employed to collect information on production constraints and farmers' preferred traits to guide pearl millet breeding programs and design new varieties that meet farmer needs and preferences [4]. However, the study area was limited to only three districts, and there were a few respondents. Therefore, the objective of the current study was to include more sites and more respondents to have a broader data set to document farmers' perceptions on the prevailing constraints affecting pearl millet production. Special emphasis was placed on their approaches to managing $S$. hermonthica to guide the future development and release of improved and locally acceptable varieties to farmers in Burkina Faso.

\section{Materials and Methods}

\subsection{Description of the Study Sites}

Burkina Faso has a tropical climate consisting of a long dry season (November to May) and a short rainy season (June to October). Pearl millet is cultivated in the short rainy season. The study was conducted in the Sahelian and Sudano-Sahelian agro-ecological zones of Burkina Faso, where much of the pearl millet is produced (Figure 1). The Sahelian zone receives less than $600 \mathrm{~mm}$ of rainfall with monthly mean temperatures between 24 and $35.3^{\circ} \mathrm{C}$ during the short rainy season between 2 and 3 months. The Sudano-Sahelian zone receives rainfall between $600-900 \mathrm{~mm}$ over 4 to 5 months, with mean temperatures between 25 and $33.5^{\circ} \mathrm{C}$ [18]. The predominant soils are deficient in nitrogen and phosphorus due to soil erosion and high temperatures experienced in these regions [19].

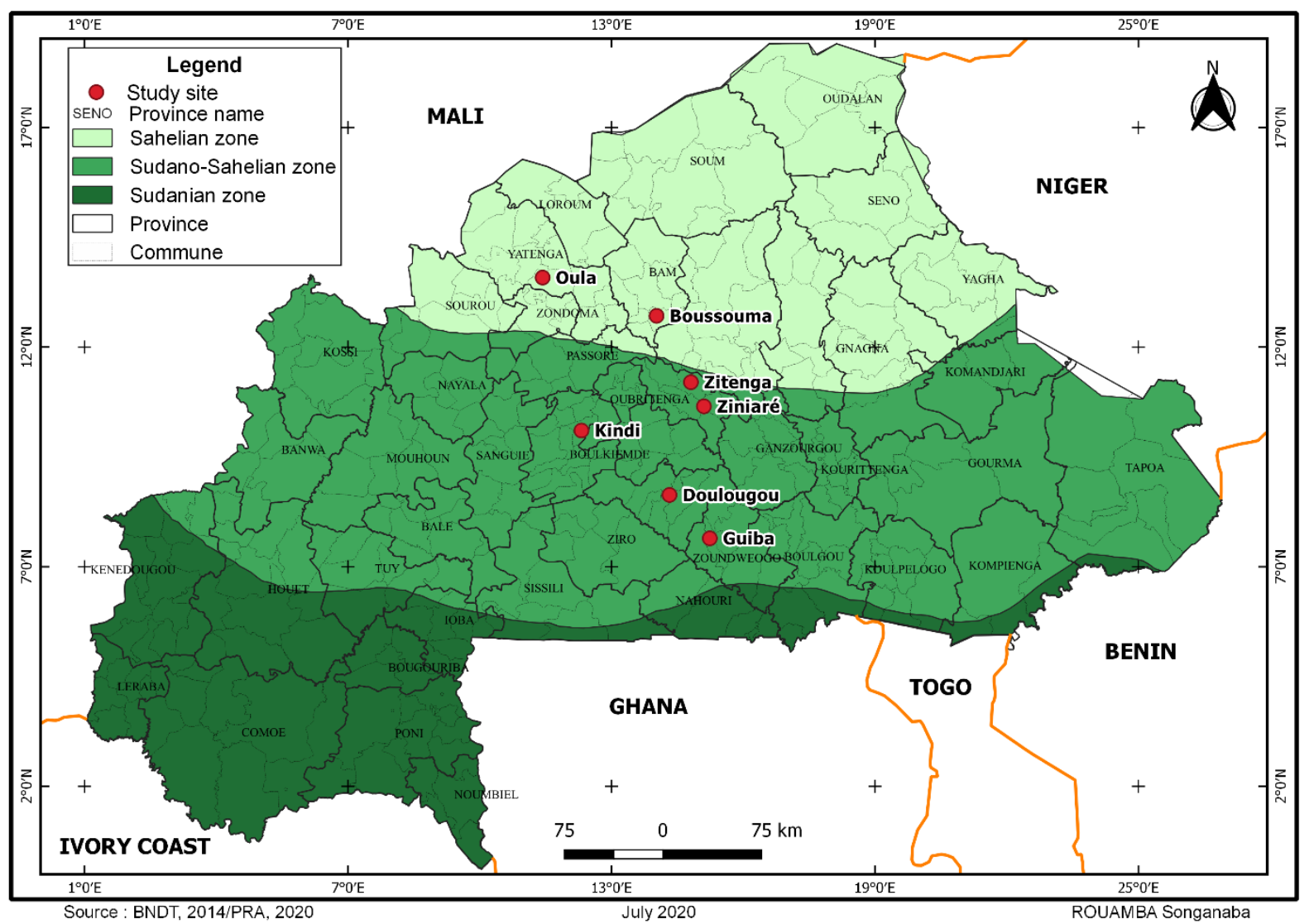

Figure 1. Map of Burkina Faso showing the common agro-ecological zones and the study sites.

\subsection{Sampling Method}

A hierarchical sampling method based on pearl millet production, S. hermonthica infestation, and the regions' administrative organisation was used to select the study sites (Figure 2). Secondary data on pearl millet production and S. hermonthica infestation were 
obtained from the Agriculture Department [20]. Two agro-ecological zones involved in large-scale pearl millet production were selected. Subsequently, five regions were identified based on S. hermonthica infestation, and accessibility. Three regions, namely Central Plateau, South Central, and West Central, were identified in the Sudano-Sahelian agro-ecological zone, while two regions, namely North and North Central, were selected in the Sahelian zone. Six provinces were selected where S. hermonthica regularly occurs in farmers' pearl millet production fields. Additionally, the selected villages were known for their pearl millet production and Striga infestations. Farmers who experienced high S. hermonthica infestation in their fields were chosen after a preliminary survey. The sampling process was facilitated by a social scientist, breeders, key informants, and agricultural extension agents. A total of 492 respondents participated in the study. Three hundred farmers were interviewed using a structured questionnaire, and 192 farmers were part of the focus group discussion. Focus group discussions (FGD) were used to record farmers' perceptions, the main constraints in pearl millet production, and their strategies to coping with S. hermonthica infestations in the surveyed areas. The questionnaires were administered to farmers in the North, North Central, and South Central regions, while the FGD was conducted in Central Plateau and West Central regions in January and February 2020.

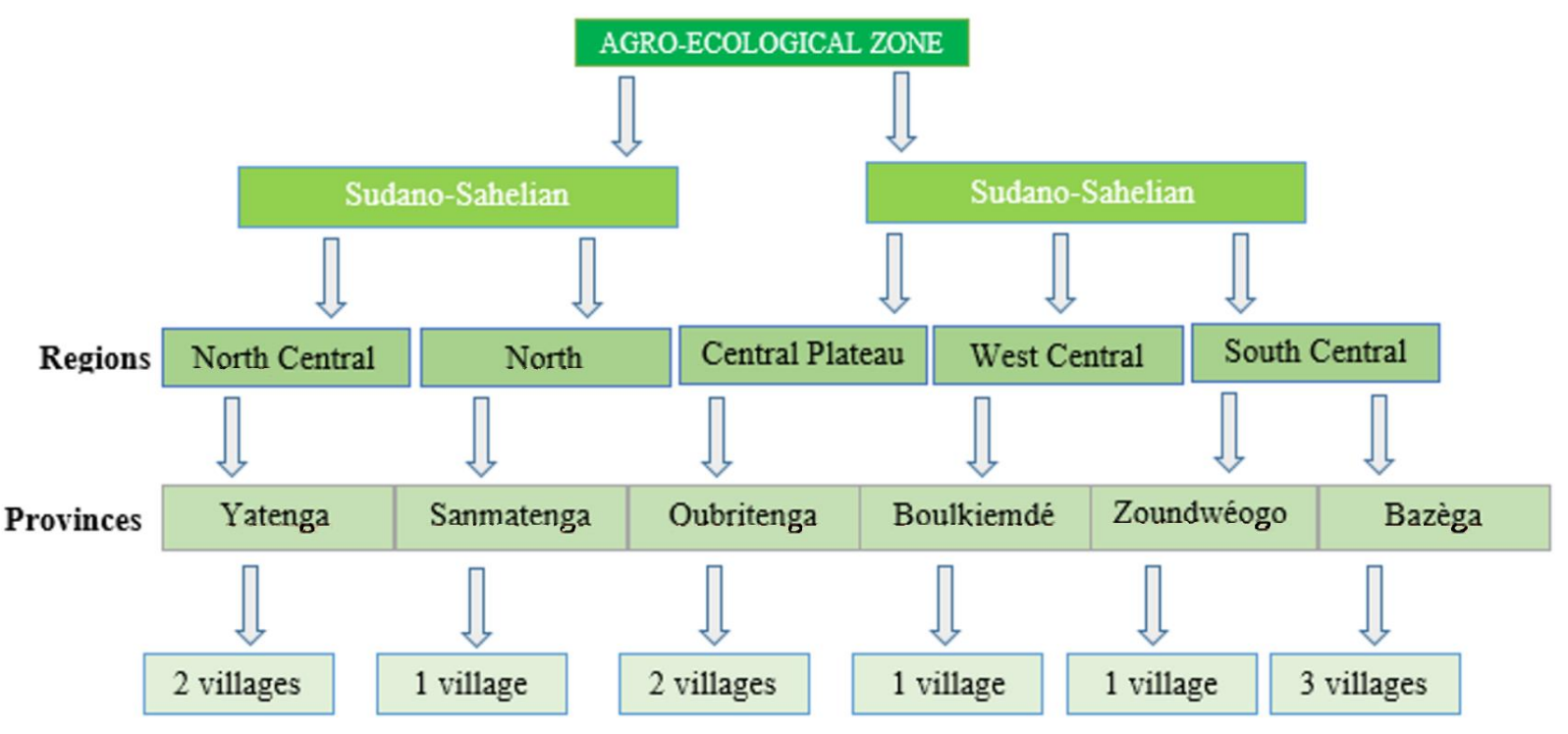

Figure 2. Sampling method cascading the selected zones, regions, provinces, and villages for the study.

\subsection{Data Collection and Analyses}

Data were collected through interviews using a structured open- and closed-ended questions and focus group discussions (Figure 3). Leaders of farmers' organisations in each village were involved in facilitating focus group discussions and administering the questionnaires. The questionnaires were pre-tested before conducting the actual data collection from farmers. The pre-test was undertaken to streamline the questionnaire and avoid ambiguous questions and improve the clarity of questions. The focus group discussions included an exhibition of photos with S. hermonthica and its associated damage, transect walks, and the discussions were recorded in writing and audio formats. The constraints identified in the questionnaires were further explored in more detail and ranked using a pair-wise matrix technique during the focus group discussions. 


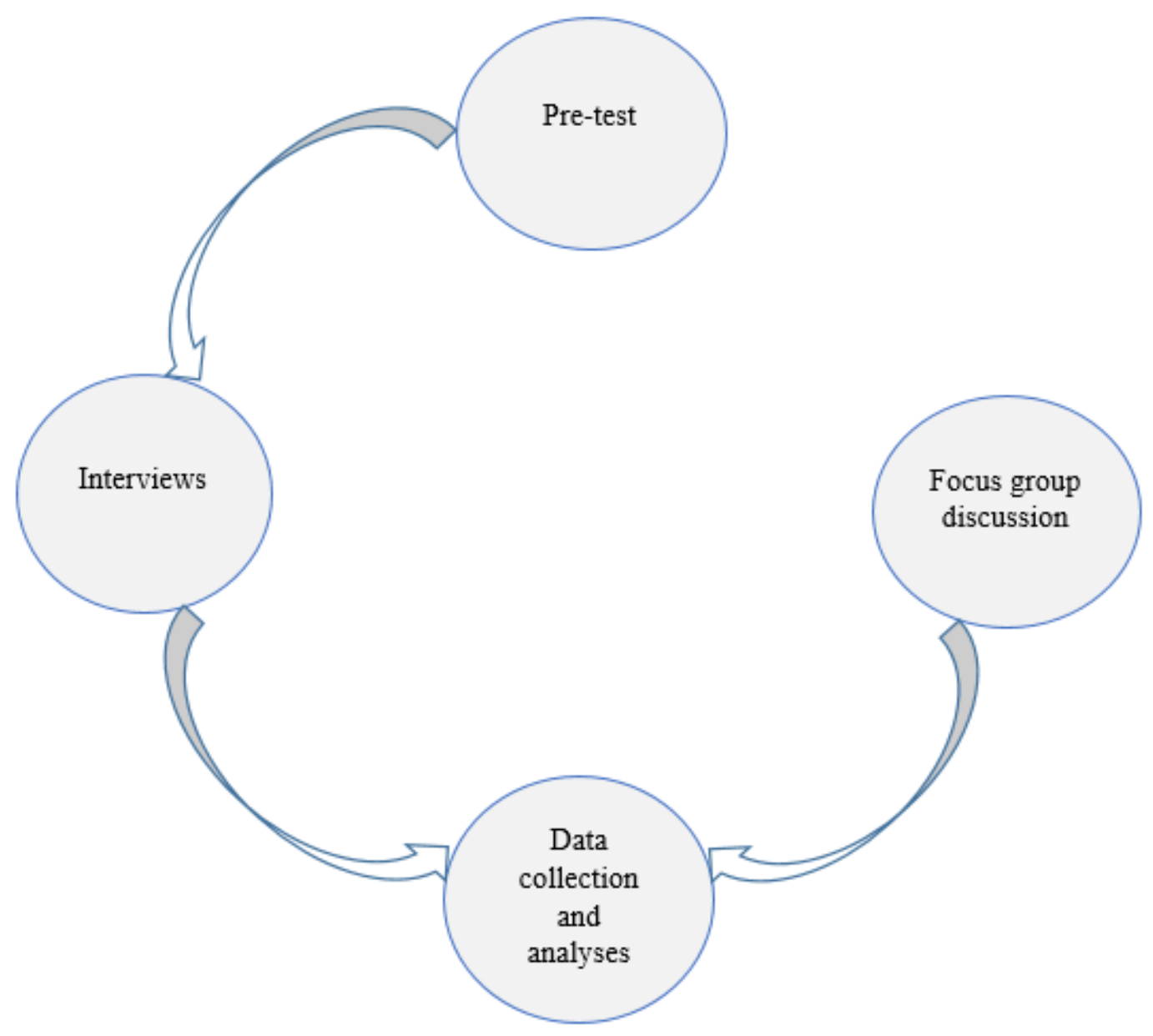

Figure 3. The interface of data collection and analysis during the study.

Qualitative data sets collected through the questionnaire were coded into district categories and subjected to statistical analyses using the 2005 version of the Statistical Package for Social Sciences software (SPSS Inc. Chicago, IL, USA). Cross-tabulations were computed, tables were constructed, and descriptive statistics were performed to summarise data from the questionnaires and FGDs. The pair-wise ranking method was used to prioritize the constraints raised during FGDs. To make statistical inferences, contingency Chi-Square tests were conducted to determine relationships among the different variables.

\section{Results}

\subsection{Sociodemographic Description of Respondent Farmers}

Three hundred smallholder farmers were interviewed individually using structured questionnaires, while 192 farmers were involved in focus group discussions. The demographic characteristics of participants are presented in Table 1 . The number of male or female respondents varied significantly between the regions $\left(X^{2}=18.349 ; p<0.000\right)$ across the different zones. The North zone had the least male respondents $(36 \%)$, while South Central had $65 \%$ male representation ( $n=100$ per surveyed region). About $80 \%$ of the non-disabled population are involved in the agriculture sector in Burkina Faso.

Fifty-three percent of the farmers were above 50 years old, while $34 \%$ were between 30 and $50(n=300)$. The low number of individuals below 30 years indicates the rural to urban migration of youths in pursuit of urban livelihoods. The distribution of farmers in the different age groups showed similarities across the different zones. The majority $(51 \%)$ of households had a family size of 1 to 10 individuals, while close to $40 \%$ had up to 20 individuals $(n=300)$ suggesting the high population growth rate in addition to the practice of polygamy in the rural areas. The trend was similar across the zones. Relatively few of 
the respondents $(8.3 \%)$ had attended primary school, secondary school $(1.3 \%)$, and college $(0.4 \%)$ and were able to read and write. The remaining $90 \%$ did not attend formal schools and experienced difficulties in reading and writing $(n=300)$.

Table 1. Social and demographic information of respondent farmers during the study in three regions in Burkina Faso (\%; $n=300)$.

\begin{tabular}{|c|c|c|c|c|c|c|c|c|}
\hline \multirow{2}{*}{ Variable } & \multirow{2}{*}{ Class } & \multicolumn{3}{|l|}{ Regions } & \multirow{2}{*}{ Mean } & \multirow{2}{*}{ df } & \multirow{2}{*}{ Chi-Square } & \multirow{2}{*}{$p$-Value } \\
\hline & & North Central & South Central & North & & & & \\
\hline \multirow{2}{*}{ Gender } & Male & 43 & 65 & 36 & 48 & \multirow[b]{2}{*}{2} & \multirow{2}{*}{18.349} & \multirow[b]{2}{*}{0.000} \\
\hline & Female & 57 & 35 & 64 & 52 & & & \\
\hline \multirow{3}{*}{ Family size } & $1-10$ & 49 & 62 & 43 & 51.3 & \multirow{3}{*}{4} & \multirow{3}{*}{65.370} & \multirow{3}{*}{0.183} \\
\hline & $11-20$ & 45 & 32 & 42 & 39.7 & & & \\
\hline & $>20$ & 6 & 6 & 15 & 9 & & & \\
\hline \multirow{3}{*}{ Age (years) } & $<30$ & 16 & 10 & 12 & 12.7 & \multirow{3}{*}{4} & \multirow{3}{*}{136.094} & \multirow{3}{*}{0.060} \\
\hline & $30-50$ & 43 & 61 & 55 & 53 & & & \\
\hline & $>50$ & 41 & 29 & 33 & 34.3 & & & \\
\hline \multirow{3}{*}{ Marital status } & Married & 97 & 85 & 94 & 92 & \multirow{3}{*}{4} & \multirow{3}{*}{11.048} & \multirow{3}{*}{0.026} \\
\hline & Single & 0 & 3 & 1 & 1.3 & & & \\
\hline & Widowed & 3 & 12 & 5 & 6.7 & & & \\
\hline \multirow{4}{*}{ Education level } & Literate & 96 & 88 & 86 & 90 & \multirow{4}{*}{6} & \multirow{4}{*}{11.242} & \multirow{4}{*}{0.081} \\
\hline & $\begin{array}{l}\text { Primary } \\
\text { school }\end{array}$ & 3 & 11 & 11 & 8.3 & & & \\
\hline & $\begin{array}{l}\text { Secondary } \\
\text { school }\end{array}$ & 1 & 0 & 3 & 1.3 & & & \\
\hline & Graduate & 0 & 1 & 0 & 0.4 & & & \\
\hline
\end{tabular}

df, degrees of freedom.

\subsection{Main Socio-Economic Activities in the Study Provinces} Income Sources

Crop production was the single most common source of income among the respondent farmers, with $36.7 \%$ affirming that they derived income from crop production (Table 2). The second most important income source was a combination of crop and livestock production, as indicated by $21.0 \%$ of the farmers. In comparison, about $18.0 \%$ of the respondents earned income from either livestock production alone or businesses such as in small shops $(n=300)$. Most of the respondents derived their livelihood from agriculture in one form or the other. Farmers practice mixed farming - a combination of livestock rearing and crop production to pursue food security and livelihoods.

\subsection{Pearl Millet Varieties Grown in the Study Areas}

Several different crops were grown in the study area, as confirmed by the respondent farmers and observation made during transect walks (Table 3). The majority of the farmers used local varieties of pearl millet, while $32 \%$ adopted improved varieties. However, there were significant variations among the different regions. For instance, almost all of the farmers $(93 \%)$ in the North Central region cultivated improved pearl millet varieties owing to the support given by the local non-governmental organisations NGOs. In contrast, in the South Central and North regions, 80 and $97 \%$ of respondents, respectively, cultivated local varieties. This is due to the limited research support to pearl millet when compared with other major crops such as maize and rice ( $n=100$ in each region). 
Table 2. Income source according to the regions $(\% ; n=300)$.

\begin{tabular}{|c|c|c|c|c|c|c|c|}
\hline \multirow{2}{*}{ Income Source } & \multicolumn{3}{|c|}{ Regions } & \multirow{2}{*}{ Mean } & \multirow{2}{*}{ df } & \multirow{2}{*}{ Chi-Square } & \multirow{2}{*}{$p$-Value } \\
\hline & North Central & South Central & North & & & & \\
\hline Crop production & 43 & 7 & 60 & 36.7 & & & \\
\hline Livestock production & 4 & 41 & 11 & 18.7 & & & \\
\hline $\begin{array}{l}\text { Crop and livestock } \\
\text { production }\end{array}$ & 49 & 0 & 14 & 21.0 & & & \\
\hline Tuckshop & 3 & 45 & 5 & 17.7 & 16 & 2.326 & 0.000 \\
\hline $\begin{array}{l}\text { Crop production and } \\
\text { tuckshop }\end{array}$ & 0 & 0 & 8 & 2.7 & & & \\
\hline Craftmanship & 0 & 3 & 1 & 1.3 & & & \\
\hline Gardening & 0 & 3 & 1 & 1.3 & & & \\
\hline $\begin{array}{l}\text { Livestock production and } \\
\text { tuckshop }\end{array}$ & 0 & 1 & 0 & 0.3 & & & \\
\hline $\begin{array}{l}\text { Processing of crop } \\
\text { products }\end{array}$ & 1 & 0 & 0 & 0.3 & & & \\
\hline
\end{tabular}

df, degrees of freedom.

Table 3. Proportion of farmers using different crop varieties in the study area $(\% ; n=300)$.

\begin{tabular}{|c|c|c|c|c|c|c|c|c|}
\hline \multirow{2}{*}{ Crop } & \multirow{2}{*}{ Varieties } & \multicolumn{3}{|c|}{ Regions } & \multirow{2}{*}{ Mean } & \multirow{2}{*}{ df } & \multirow{2}{*}{ Chi-Square } & \multirow{2}{*}{$p$-Value } \\
\hline & & North Central & South Central & North & & & & \\
\hline \multirow{2}{*}{ Pearl millet } & Local & 6 & 80 & 97 & 61 & \multirow{2}{*}{2} & \multirow{2}{*}{2876} & \multirow{2}{*}{0.000} \\
\hline & Improved & 93 & 0 & 3 & 32 & & & \\
\hline \multirow{2}{*}{ Sorghum } & Local & 14 & 79 & 43 & 45.3 & \multirow[b]{2}{*}{2} & \multirow{2}{*}{106.840} & \multirow{2}{*}{0.000} \\
\hline & Improved & 25 & 0 & 3 & 9.3 & & & \\
\hline \multirow{2}{*}{ Cowpea } & Local & 5 & 56 & 40 & 33.7 & \multirow[b]{2}{*}{2} & \multirow[b]{2}{*}{169.769} & \multirow[b]{2}{*}{0.000} \\
\hline & Improved & 81 & 12 & 6 & 33 & & & \\
\hline \multirow{2}{*}{ Maize } & Local & 0 & 50 & 23 & 24.3 & \multirow[b]{2}{*}{2} & \multirow{2}{*}{166.425} & \multirow{2}{*}{0.000} \\
\hline & Improved & 1 & 37 & 6 & 14.7 & & & \\
\hline \multirow{2}{*}{ Groundnut } & Local & 4 & 30 & 44 & 26 & \multirow{2}{*}{2} & \multirow{2}{*}{101.267} & \multirow{2}{*}{0.000} \\
\hline & Improved & 34 & 0 & 0 & 11.3 & & & \\
\hline \multirow{2}{*}{ Sesame } & Local & 0 & 2 & 6 & 2.7 & \multirow{2}{*}{2} & \multirow{2}{*}{13.090} & \multirow{2}{*}{0.011} \\
\hline & Improved & 3 & 0 & 0 & 1 & & & \\
\hline \multirow{2}{*}{ Bambara nut } & Local & 4 & 1 & 4 & 3 & \multirow{2}{*}{2} & \multirow{2}{*}{72.177} & \multirow{2}{*}{0.000} \\
\hline & Improved & 31 & 0 & 0 & 10.3 & & & \\
\hline \multirow{2}{*}{ Rice } & Local & 0 & 5 & 0 & 16.7 & & & \\
\hline & Improved & 0 & 4 & 0 & 1.3 & 2 & 18.557 & 0.001 \\
\hline
\end{tabular}

df, degrees of freedom.

\subsection{Status of Pearl Millet Production}

Table 4 represents the mean area allocated to pearl millet production in the study sites between 2015 and 2019. About $23 \%$ of the interviewed farmers allocated less than one hectare (ha) of land to pearl millet production, while $62.6 \%$ have less than two hectares $(n=300)$. Ancestral or family land ownership was confirmed by $87 \%$ of the respondents $(n=300)$. The mean yield produced and reported is presented in Table 5. Most of the respondents $(61.4 \%)$ harvest grain yields less than 1 ton ha ${ }^{-1}$, while the mean yield achieved in S. hermonthica-free pearl millet fields was between 0.5 and 2.0 ton ha ${ }^{-1}(n=300)$. Globally, pearl millet production is estimated with a mean yield of 0.89 ton ha ${ }^{-1}$ [21]. The trend of pearl millet production area during the last five years is the same across the study area. This is mainly attributed to a lack of agricultural lands leading to monoculture systems and lowering soil fertility and enhancing Striga infestation and development. In Burkina Faso a blanket recommendation of $100 \mathrm{~kg}$ nitrogen, phosphorus, and potassium (NPK) and $50 \mathrm{~kg}$ of urea fertilizers and $5 \mathrm{~kg}$ crop seed per hectare are used for pearl millet production. 
Table 4. Trends of pearl millet production area in the study areas from 2015-2019.

\begin{tabular}{|c|c|c|c|c|c|c|c|c|c|c|c|}
\hline \multirow{2}{*}{ Year } & \multirow{2}{*}{ Regions } & \multicolumn{7}{|c|}{ Production Areas (ha) and Number of Respondents } & \multirow{2}{*}{ df } & \multirow{2}{*}{ Chi-Square } & \multirow{2}{*}{$p$-Value } \\
\hline & & {$[0-1]$} & [1-2] & [2-3] & [3-4] & {$[4-5]$} & {$[5-6]$} & [6-7] & & & \\
\hline \multirow[t]{3}{*}{2015} & $\begin{array}{l}\text { South } \\
\text { Central }\end{array}$ & 26 & 10 & 0 & 0 & 0 & 0 & 0 & \multirow{3}{*}{12} & \multirow{3}{*}{119.895} & \multirow{3}{*}{0.000} \\
\hline & North & 15 & 43 & 25 & 8 & 1 & 1 & 0 & & & \\
\hline & $\begin{array}{l}\text { North } \\
\text { Central }\end{array}$ & 10 & 27 & 24 & 19 & 3 & 0 & 1 & & & \\
\hline Total & & 51 & 80 & 49 & 27 & 4 & 1 & 1 & & & \\
\hline \multirow[t]{3}{*}{2016} & $\begin{array}{l}\text { South } \\
\text { Central }\end{array}$ & 23 & 13 & 1 & 0 & 0 & 0 & 0 & \multirow{3}{*}{12} & \multirow{3}{*}{102.140} & \multirow{3}{*}{0.000} \\
\hline & North & 14 & 42 & 26 & 8 & 1 & 1 & 0 & & & \\
\hline & $\begin{array}{l}\text { North } \\
\text { Central }\end{array}$ & 11 & 27 & 25 & 20 & 2 & 0 & 1 & & & \\
\hline Total & & 48 & 82 & 52 & 28 & 3 & 1 & 1 & & & \\
\hline \multirow[t]{3}{*}{2017} & $\begin{array}{l}\text { South } \\
\text { Central }\end{array}$ & 27 & 25 & 4 & 1 & 0 & 0 & 0 & \multirow{3}{*}{12} & \multirow{3}{*}{91.024} & \multirow{3}{*}{0.000} \\
\hline & North & 16 & 44 & 28 & 8 & 1 & 1 & 0 & & & \\
\hline & $\begin{array}{l}\text { North } \\
\text { Central }\end{array}$ & 11 & 28 & 29 & 19 & 3 & 0 & 1 & & & \\
\hline Total & & 54 & 97 & 61 & 28 & 4 & 1 & 1 & & & \\
\hline \multirow[t]{3}{*}{2018} & $\begin{array}{l}\text { South } \\
\text { Central }\end{array}$ & 31 & 29 & 3 & 1 & 0 & 0 & 0 & \multirow{3}{*}{12} & \multirow{3}{*}{101.618} & \multirow{3}{*}{0.000} \\
\hline & North & 16 & 46 & 28 & 8 & 1 & 1 & 0 & & & \\
\hline & $\begin{array}{l}\text { North } \\
\text { Central }\end{array}$ & 12 & 30 & 29 & 21 & 2 & 0 & 1 & & & \\
\hline Total & & 59 & 105 & 60 & 30 & 3 & 1 & 1 & & & \\
\hline \multirow[t]{3}{*}{2019} & $\begin{array}{l}\text { South } \\
\text { Central }\end{array}$ & 49 & 26 & 4 & 1 & 0 & 0 & 0 & \multirow{3}{*}{12} & \multirow{3}{*}{113.365} & \multirow{3}{*}{0.000} \\
\hline & North & 14 & 48 & 26 & 8 & 1 & 1 & 0 & & & \\
\hline & $\begin{array}{l}\text { North } \\
\text { Central }\end{array}$ & 14 & 31 & 31 & 20 & 2 & 1 & 1 & & & \\
\hline Total & & 77 & 105 & 61 & 29 & 3 & 2 & 1 & & & \\
\hline
\end{tabular}

\subsection{Constraints to Pearl Millet Production in Burkina Faso}

Farmers mentioned that bird damage, drought, downy mildew, Psalydolytta spp, S. hermonthica, a lack of access to improved varieties, lack of fertilisers, labour unavailability, shortage of cash, lack of farm equipment, and poor soil fertility were the major challenges affecting pearl millet production (Table 6). Forty percent of the respondents ranked S. hermonthica infestation as the most important challenge of pearl millet production $(n=300)$. S. hermonthica infestation is estimated to cause up to $80 \%$ yield losses in pearl millet production according to the respondents during FGDs. Yield loss accompanied by Striga damage that lead to poor seed germination, leaf chlorosis, stunted pearl millet growth and development and plant death under heavy infestation. A lack of access to fertilisers was ranked by $34.7 \%$ of the farmers as the most important constraint due to the high costs of inorganic fertilizers, which are prohibitive for most small farmers $(n=300)$. 
Table 5. Mean grain yield of pearl millet in the study areas $(\% ; n=300)$.

\begin{tabular}{|c|c|c|c|c|c|c|c|}
\hline \multirow{2}{*}{ Yield (kg/ha) } & \multicolumn{3}{|c|}{ Regions } & \multirow{2}{*}{ Mean } & \multirow{2}{*}{ df } & \multirow{2}{*}{ Chi-Square } & \multirow{2}{*}{$p$-Value } \\
\hline & North Central & South Central & North & & & & \\
\hline [0-500] & 8 & 69 & 15 & 30.7 & \multirow{11}{*}{20} & \multirow{11}{*}{3.199} & \multirow{11}{*}{0.000} \\
\hline [500-1000] & 51 & 5 & 36 & 30.7 & & & \\
\hline [1000-1500] & 14 & 0 & 17 & 10.3 & & & \\
\hline [1500-2000] & 8 & 0 & 22 & 6.7 & & & \\
\hline [2000-2500] & 5 & 0 & 6 & 3.7 & & & \\
\hline [2500-3000] & 8 & 0 & 2 & 3.3 & & & \\
\hline [3000-3500] & 2 & 0 & 2 & 1.3 & & & \\
\hline [3500-4000] & 0 & 0 & 0 & 0 & & & \\
\hline [4000-4500] & 0 & 0 & 0 & 0 & & & \\
\hline [4500-5000] & 2 & 0 & 0 & 0.7 & & & \\
\hline [5000-5500] & 1 & 0 & 0 & 0.3 & & & \\
\hline
\end{tabular}

df, degrees of freedom.

Table 6. Number of participant farmers who ranked the constraints to pearl millet production in three regions of Burkina Faso $(\% ; n=300)$.

\begin{tabular}{|c|c|c|c|c|c|c|c|c|}
\hline \multirow{2}{*}{ Constraints } & \multirow{2}{*}{ Rank } & \multicolumn{3}{|c|}{ Regions } & \multirow{2}{*}{ Mean } & \multirow{2}{*}{ df } & \multirow{2}{*}{ Chi-Square } & \multirow{2}{*}{$p$-Value } \\
\hline & & North Central & South Central & North & & & & \\
\hline \multirow{4}{*}{ Striga hermonthica } & $1^{\text {rst }}$ & 26 & 64 & 30 & 40 & \multirow{4}{*}{6} & \multirow{4}{*}{43.524} & \multirow{4}{*}{0.000} \\
\hline & $2^{\text {nd }}$ & 48 & 17 & 7 & 24 & & & \\
\hline & $3^{\text {rd }}$ & 24 & 15 & 4 & 14.3 & & & \\
\hline & $4^{\text {th }}$ & 2 & 1 & 0 & 1 & & & \\
\hline \multirow{4}{*}{ Lack of fertilisers } & $1^{\text {rst }}$ & 47 & 16 & 41 & 34.7 & \multirow{4}{*}{6} & \multirow{4}{*}{41.471} & \multirow{4}{*}{0.000} \\
\hline & $2^{\text {nd }}$ & 47 & 36 & 32 & 38.3 & & & \\
\hline & $3^{\text {rd }}$ & 4 & 15 & 6 & 8.3 & & & \\
\hline & $4^{\text {th }}$ & 0 & 8 & 0 & 2.7 & & & \\
\hline \multirow{4}{*}{ Lack of cash } & $1^{\text {rst }}$ & 25 & 3 & 16 & 14.7 & \multirow{4}{*}{6} & \multirow{4}{*}{37.008} & \multirow{4}{*}{0.000} \\
\hline & $2^{\text {nd }}$ & 3 & 4 & 22 & 9.7 & & & \\
\hline & $3^{\text {rd }}$ & 21 & 5 & 15 & 13.7 & & & \\
\hline & $4^{\text {th }}$ & 26 & 12 & 5 & 14.3 & & & \\
\hline \multirow{4}{*}{ Drought } & $1^{\text {rst }}$ & 2 & 10 & 5 & 5.7 & \multirow{4}{*}{6} & \multirow{4}{*}{64.906} & \multirow{4}{*}{0.000} \\
\hline & $2^{\text {nd }}$ & 2 & 33 & 8 & 14.3 & & & \\
\hline & $3^{\text {rd }}$ & 26 & 9 & 10 & 15 & & & \\
\hline & $4^{\text {th }}$ & 22 & 2 & 1 & 8.3 & & & \\
\hline \multirow{4}{*}{$\begin{array}{l}\text { Lack of improved } \\
\text { varieties }\end{array}$} & $1^{\text {rst }}$ & 0 & 3 & 1 & 1.3 & \multirow{4}{*}{6} & \multirow{4}{*}{8.876} & \multirow{4}{*}{0.181} \\
\hline & $2^{\text {nd }}$ & 0 & 4 & 3 & 2.3 & & & \\
\hline & $3^{\text {rd }}$ & 2 & 23 & 4 & 9.7 & & & \\
\hline & $4^{\text {th }}$ & 3 & 24 & 1 & 9.3 & & & \\
\hline \multirow{4}{*}{ Shortage of labour } & $1^{\text {rst }}$ & 0 & 0 & 3 & 1 & \multirow{4}{*}{6} & \multirow{4}{*}{23.185} & \multirow{4}{*}{0.001} \\
\hline & $2^{\text {nd }}$ & 0 & 1 & 12 & 4.3 & & & \\
\hline & $3^{\text {rd }}$ & 4 & 18 & 5 & 9 & & & \\
\hline & $4^{\text {th }}$ & 0 & 1 & 1 & 0.7 & & & \\
\hline
\end{tabular}

\subsection{S. Hermonthica Infestation and Control Strategies}

Almost all of the farmers ( $99 \%$ ) recognized the negative impact of $S$. hermonthica on pearl millet growth and yield $(n=300)$. They understood the need for weed management for yield improvement. Hand-weeding of S. hermonthica plant and fertilizer application was the main S. hermonthica control measures reported by $90 \%$ of the respondents (Table 7 ) $(n=300)$. These methods are believed to reduce the S. hermonthica seed bank in the soil. Hand weeding was practiced by $34.7 \%$ of the farmers, while a combination of weeding by 
hand and hoe was the next most common method used by $31.0 \%$ of the farmers. Very few farmers used crop rotation and herbicides due to the lack of arable land $(n=300)$.

Table 7. S. hermonthica control measures used by farmers $(\%, n=300)$.

\begin{tabular}{|c|c|c|c|c|c|c|c|}
\hline \multirow{2}{*}{ S. hermonthica Control Measures } & \multicolumn{3}{|c|}{ Regions } & \multirow{2}{*}{ Mean } & \multirow{2}{*}{ df } & \multirow{2}{*}{ Chi-Square } & \multirow{2}{*}{$p$-Value } \\
\hline & North Central & South Central & North & & & & \\
\hline Hand weeding & 57 & 47 & 0 & 34.7 & \multirow{14}{*}{26} & \multirow{14}{*}{3.063} & \multirow{14}{*}{0.000} \\
\hline Hand weeding and hoeing & 0 & 21 & 72 & 31.0 & & & \\
\hline $\begin{array}{l}\text { Crop rotation, intercropping, } \\
\text { and hand weeding }\end{array}$ & 26 & 0 & 0 & 8.7 & & & \\
\hline Use of organic manure and hoeing & 0 & 8 & 0 & 2.7 & & & \\
\hline $\begin{array}{l}\text { Intercropping with cowpea and } \\
\text { hand weeding }\end{array}$ & 5 & 0 & 0 & 1.7 & & & \\
\hline Intercropping, hand weeding & 5 & 0 & 0 & 1.7 & & & \\
\hline Hoeing & 0 & 0 & 4 & 1.3 & & & \\
\hline Crop rotation and hand weeding & 3 & 0 & 0 & 1.0 & & & \\
\hline Crop rotation and intercropping & 2 & 0 & 0 & 0.7 & & & \\
\hline $\begin{array}{l}\text { Micro plots, crop rotation, } \\
\text { hand weeding }\end{array}$ & 1 & 0 & 0 & 0.3 & & & \\
\hline Crop rotation and hand weeding & 1 & 1 & 0 & 0.7 & & & \\
\hline $\begin{array}{l}\text { Hand weeding and use of } \\
\text { herbicides }\end{array}$ & 0 & 0 & 1 & 0.3 & & & \\
\hline $\begin{array}{l}\text { Hand weeding and use of inorganic } \\
\text { fertilisers }\end{array}$ & 0 & 1 & 0 & 0.3 & & & \\
\hline Use of inorganic Fertilisers & 0 & 1 & 0 & 0.3 & & & \\
\hline
\end{tabular}

df, degrees of freedom.

The farmers used various soil moisture conservation methods (Figure 4, Table 8), as a tool to control S. hermonthica. Terraces, mulching, the use of micro plots or planting holes (locally referred to as zai), ridges, and grass strips were some of the techniques used for moisture conservation and to suppress the impact of $S$. hermonthica (Figure 4, Table 8) $(n=300)$. Terraces, mulching, ridges, and grass strips are used to reduce ran off during the raining season, allowing water to be conserved and infiltrate into the soil. Micro plots or planting holes is a traditional technique used to conserve moisture and increase soil fertility to favour pearl millet production.

Table 8. Percentages of participant farmers who reported the use of moisture conservation methods in the study areas $(n=300)$.

\begin{tabular}{lllllll}
\hline \multirow{2}{*}{$\begin{array}{l}\text { Moisture Conservation } \\
\text { Method }\end{array}$} & North Central & South Central & North & Mean & df & Chi-Square \\
\cline { 2 - 5 } & 99 & 77 & 89 & 88.3 & \\
\hline Terraces & 0 & 13 & 0 & 4.3 & \\
Mulches & 0 & 5 & 0 & 1.7 & 8 & 42.885 \\
Ridges & 0 & 2 & 3 & 1.7 & & 0.000 \\
Micro plots/planting holes & 0 & 1 & 0 & 0.3 & \\
Grass stripes & & & & & \\
\hline
\end{tabular}




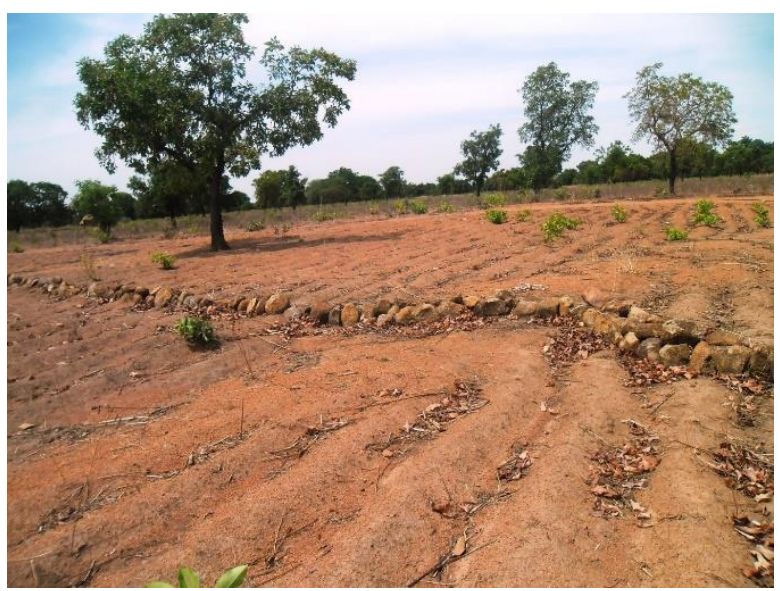

(A)

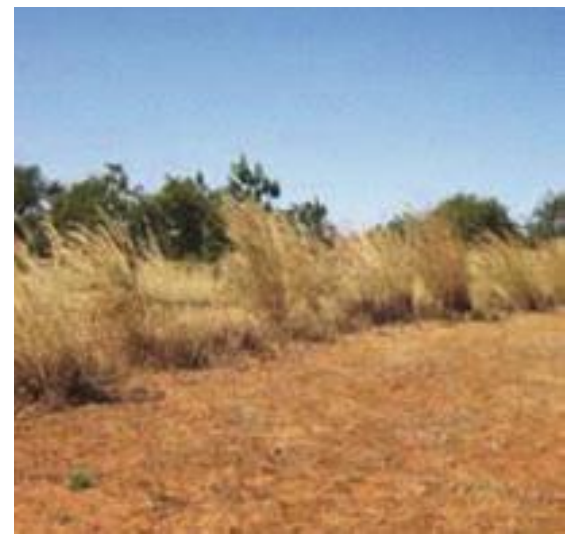

(C)

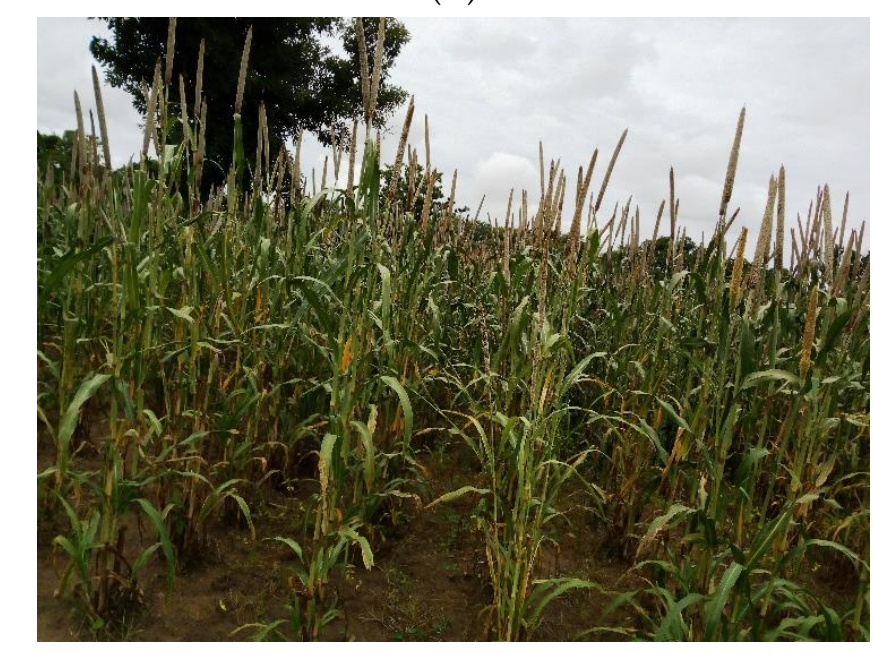

(E)

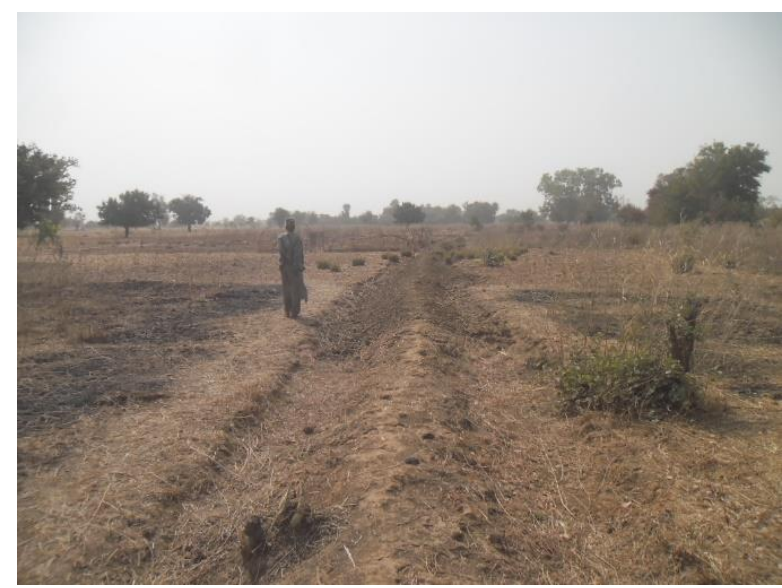

(B)

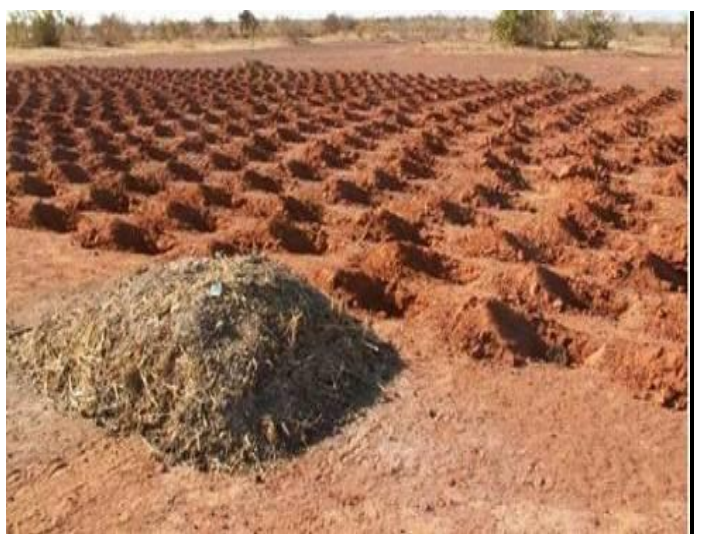

(D)

Figure 4. The common soil moisture conservation methods in pearl millet production fields in Burkina Faso to suppress S. hermonthica infestation. Note: $(\mathbf{A})=$ terrace, $(\mathbf{B})=$ ridge,$(\mathbf{C})=$ grass strips, $(\mathbf{D})=$ micro plots or planting holes $($ zaii), and (E): field/crop of pearl millet (Photo by Rouamba 2020 (A,B,E); Botoni et Reij, 2001 (D), GIZ 2012 (C).

\section{Discussion}

\subsection{Social and Demographical Description of Respondent Farmers}

The study found an almost equal representation of female (52\%) and male (48\%) respondent farmers involved in pearl millet cultivation in the study areas (Table 1). The active participation of women pearl millet farmers is critical in pursuing food security in 
the country. Women play important roles in crop production and strengthening social networks [22]. The participation of women in this study was important to facilitate discussions and capture women farmers' perspectives because they are often underrepresented in agricultural interventions. It is also important because the lessons will cascade down to family and households, given women's multiple roles in providing household welfare. Previously, more female farmers were reported to be involved in producing crops such as Bambara groundnut in Ghana and improved agricultural technologies and practices in sub-Saharan Africa compared to male farmers [23,24].

Most participants were between 30 and 50 years of age and married (Table 1), an appropriate and active demographic group for decision-making, farm operations, and participation in the local economy. In African tradition, age and marital status are highly influential traits for making decisions such as the type of crop and variety to cultivate and land allocation that an individual can make in a household, directly impacting pearl millet production. Thus, having the majority of the participants in this demographic group was important to obtain relevant information, since most respondents were experienced in pearl millet production and encountered the constraints they perceived to be important, know some management options, and influence decisions made in the household. For instance, youths and widowed female farmers are usually at the bottom of the decision-making pyramid as they usually take directives from an older and male household head. In addition, household dynamics are also determined by family size, especially for farming operations. Most subsistence farming operations are carried out by family members [25]. Households with many family members can carry out diverse farming operations, particularly during the harvesting and processing season when labour is scarce [26]. This gives such households with large families the advantage of being able to farm on larger areas. There were no significant differences among the different zones in terms of family sizes because, in Burkina Faso, families are large, often with over eight people per household, due to the extended family system prevalent across the country [27]. Despite the large families, the farmers owned small landholdings, which negatively impacted their ability to expand their production, leading to inefficient labour practices. The small landholdings are traditionally owned along ancestral lineage and controlled by the most senior male of the family [28].

Most farmers had no formal education (Table 1), which will complicate communication processes, such as extension services, adoption of improved technologies, and access to information. Farmers with limited formal education are often unwilling to adopt new technologies and have shown a strong tendency to rely on traditional knowledge and experience. Therefore, intervention strategies that include a change in farmer behavior will likely be well-received as the level of education increases among the farmers. Literate farmers usually take the initiative and participate in developmental projects to improve agricultural practices. In contrast, farmers with little or no education are usually passive, depend on receiving information and are not proactive in participatory approaches to find solutions [29]. The low literacy rate among farmers found in this study corroborated earlier findings reported by PNDES [30]. The education level among farmers has strong implications for devising intervention strategies to improve agricultural productivity in developing countries. Farmers with strong educational backgrounds could be useful as agents to gather information regarding new interventions and play important roles as leaders in technology adoption [26].

\subsection{Main Socio-Economic Activities in the Study Provinces Income Sources}

Many of the respondents derived their livelihood from agriculture in one form or the other (Table 2), as is typical in most developing countries. Sorgho [31] estimated that agriculture accounted for $76.3 \%$ of Burkina Faso's economy, showing that it was integral to sustaining livelihoods. However, agriculture faces several challenges, including low mechanization levels for intensifying production, poor sustainability, and a lack of 
agricultural credit access that impede agricultural expansion [30]. These challenges limit agricultural productivity and make farming communities vulnerable to natural disasters such as severe droughts. The farmers in the study sites are highly vulnerable because they have no alternative sources of food or money if there is a crop failure or their livestock dies. It is crucial to build a resilience in their systems against unexpected stresses notably from climate change. One method might be to increase the participation of the local farmers in value addition on their agricultural products. Some of the respondents $(17.7 \%)$ generated some income by selling household wares such as groceries and toiletries in small shops. Still, they alluded to the fact that the viability and profitability of such enterprises were dependent on a good harvest in the area, which creates disposable income for the region (Table 2). During drought years, leading to crop failure and livestock deaths, other enterprises suffer significantly because most clients are farmers who depend on crop sales for disposable income to spend on household goods [32].

\subsection{Pearl Millet Varieties Grown in the Study Areas}

The farmers were cultivating a range of crops dominated by local varieties, common among subsistence farmers who often lack resources to buy seeds of improved varieties (Table 3). However, there were significant differences between the zones in terms of the pearl millet varieties cultivated. Varietal choices can vary due to localized challenges or opportunities. Farmers who have access to extension services, agricultural inputs, and novel information usually cultivate more improved cultivars than farmers who live in inaccessible areas, farther away from agro-dealers. The majority of farmers in the North Central zone cultivated improved cultivars (Table 3). The widespread adoption of improved cultivars in North Central could be attributed to several agricultural and livelihood projects established with the support of various non-governmental organisations (NGOs) working with farmers and more active extension services in this region than in the other regions.

Many farmers used local varieties by retaining seeds for the next cycle of planting. For example, superior panicles of local pearl millet varieties would be selected and conserved for seed for the next season at harvest time. The use of retained seed is common among smallholder farmers in Africa, as reported in Uganda, where $92 \%$ of farmers used local varieties [33], and in Nigeria, where $80 \%$ of farmers used farm-retained seed [17]. However, the cultivation of local varieties is one factor contributing to the low yields attained by most farmers in the study areas (Table 5).

Local varieties are often highly adapted to their agroecology, perform relatively well in marginal environments, with minimal inputs, and have been selected for cooking qualities appropriate for preparing traditional foods [34]. However, many have low yield potential and lack uniformity compared to improved cultivars bred for yield. The adoption of improved varieties is limited by seed costs and a lack of access to seed by the local farmers. In addition, the improved varieties often do not meet cooking quality criteria [16].

In Burkina Faso, the commercial seed industry for traditional crops such as sorghum and pearl millet is not well developed. This limits seed distribution to distant communities in rural areas. Low adoption rates of improved cultivars may also be related to skepticism among the farmers for varieties that they are not familiar with, and sometimes the susceptibility to pest/disease of some improved varieties, which do not have essential farmer preferred traits [22]. Local pearl millet varieties were mainly used in the North, South Central, West Central, and Central Plateau regions. The predominance of local varieties in these regions is due to a poorly developed seed system, especially for neglected crops such as pearl millet, and a poor extension service in these regions. Farmers in these regions have little access to information, extension services, and seed supply, which leaves them entirely dependent upon farm-saved seeds of local varieties.

Improved varieties such as IKMP 5 and MISARI, which are medium maturing and have a high yield potential of above 2.00 tons ha ${ }^{-1}$, were widely cultivated in the North Central region, where access to seed and to extension services was better established. The farmer-preferred traits in pearl millet in Burkina Faso have been documented by 
Drabo et al. [4]. They include large-sized panicles that are compact and non-bristled, large grain size, medium plant height, early maturity, medium panicle length, and wide panicle diameter. In any breeding program, it would be vital to integrate these traits during cultivar development to ensure a high adoption rate for newly improved varieties of pearl millet in the study areas. It has been noted that involving farmers and other stakeholders during variety design and development increases adoption rates of improved cultivars [33]. A PRA provides an opportunity to bridge the gap between farmers' expectations and breeders' objectives for cultivar development. Previously plant breeders were more focused on developing modern varieties with high productivity in optimal and intensively managed environments. In reality, most farmers operate in sub-optimal environments and select varieties specifically adapted for production under marginal growing environments, with particular quality traits [22]. Breeders must understand farmers' conditions and expectations to breed suitable cultivars with high adoption rates.

\subsection{Pearl Millet Production}

This study showed that farmers allocated between one and three hectares of land for pearl millet production (Table 4), which is common for subsistence farmers who have small landholdings passed on from a previous generation under the traditional ownership system of inheritance. The land tenure system is a major challenge for agricultural development in smallholder communities. The landholdings are too small for substantial production, and there is no formal security of tenure, limiting the incentives for capital investments. In Africa, small farms of less than 2 ha represent $80 \%$ of all farms [35], contributing to non-commercialization and little or no mechanization of farm operations.

The farmers continue to use traditional and often inefficient agricultural practices because there is no incentive to improve methods because yields are often too low to offset investment costs on smallholdings (Table 5). The majority of farmers (87\%) use ancestral land, while the female farmers were cultivating land belonging to their marital family. The lack of land ownership rights among women is also a challenge for agricultural development. Single or widowed female farmers are the most disadvantaged in land ownership because they cannot own land and may be removed from the lands that they are farming if the husband/male figure dies [28]. This takes away their decision-making powers in terms of cropping practices and contribution to agricultural development. In terms of variety design and development, female farmers' preferences are often overridden by the dominant male farmers, who are the landowners. This also affects cultivar adoption because cultivars that male farmers prefer are adopted to a larger extent than those cultivars that incorporate traits preferred by female farmers. For instance, the adoption of improved maize varieties in Malawi by females was about $12 \%$ lower than their male counterparts [36], showing that women are often sidelined in varietal adoption.

\subsection{Constraints to Pearl Millet Production}

The farmers mentioned that damage from birds, drought stress, downy mildew disease, cantharid beetles, S. hermonthica, lack of improved varieties, lack of fertilisers, a shortage of labour at critical stages, a shortage of cash, a lack of equipment, and soil infertility were the most important challenges affecting pearl millet production in their environments. S. hermonthica infestation was ranked as the most important challenge to pearl millet production (Table 6). Almost all the farmers mentioned that they experience S. hermonthica infestation in their fields. A transact walk across the farms showed that S. hermonthica infestation was widespread. The lack of resources for S. hermonthica control, poor soil fertility, and drought contributed to the proliferation of the weed in this area. The abundance of $S$. hermonthica is attributed to its ability to produce many seeds that remain viable for many years, even under harsh conditions [37]. The S. hermonthica weed is prevalent in most semi-arid regions of sub-Saharan Africa, north of central Tanzania.

Ouedraogo et al. [38] found that S. hermonthica was a devastating weed in sorghum, while Dawud et al. [17] also reported that $S$. hermonthica was the main constraint affecting 
pearl millet production in Nigeria. According to the respondents, S. hermonthica infestation can cause up to $80 \%$ yield loss in pearl millet, making it the most important constraint of pearl millet production. In some places, farmers ended up abandoning S. hermonthicainfested pearl millet fields or replaced the pearl millet with sorghum, which is more tolerant to $S$. hermonthica $[4,33]$. The other important constraint to pearl millet production is that most farmers have limited access to fertilizers. The soils in the study area are sandy with low fertility levels, which increase $S$. hermonthica infestation and result in poor crop yields. The Sahel and Sudano-Sahel regions account for some of the most degraded and infertile soils in sub-Sahara Africa [7,9]. As a result, most soils require supplemental fertilizers to increase plant-available nutrients. Although pearl millet is relatively resilient and has a dense root system, the highly degraded nature of the soils provides minimal nutrients to support proper plant growth, which significantly reduces achievable yields.

The lack of access to financial resources, land tenure policies, and high fertilizer costs exacerbate the shortage and lack of fertilizer inputs. Suboptimal fertilizer use among farmers in marginal environments has also been reported across Africa [33]. Land shortages, a lack of access to extension services, a lack of land tenure resulting in a lack of access to financial credit, and high labour costs have been reported previously as constraints to pearl millet production $[17,33]$. These challenges will affect even improved cultivars of pearl millet. Therefore, it is essential to develop the agricultural support system parallel to cultivar design and development. It will be futile to deploy improved cultivars into a poorly developed agriculture system where farmers lack ancillary support to boost their agricultural potential. For instance, the lack of adoption of improved cultivars has been attributed partially to the non-performance of some improved cultivars [39]. However, the inadequate support systems could be partly responsible for the poor performance of the improved cultivars. Thus, it is essential to improve the agricultural environment concurrently with variety design and development for the highest impact on crop productivity, food security, and rural farmer development.

\subsection{S. hermonthica Infestation and Control Strategies}

The farmers recognized that $S$. hermonthica was detrimental to plant growth and reduced yield potential. Therefore, they employed various measures to control the weed. The control measures included hand-weeding of S. hermonthica plant, weeding, and fertiliser application (Tables 7 and 8), which had varying success rates, depending on the extent of infestation and time of intervention. To a large extent, these methods helped reduce the S. hermonthica seed bank in the soil and conserve soil moisture, which increased yield potential. The methods were readily available to the farmers since they depend on family labour for these operations. Most farmers lack resources such as equipment or financial means to acquire pesticides, which leaves them with minimal options but to use hand weeding and hoeing. Crop rotations are not feasible due to limitations in the size of their landholdings and given the long life of S. hermonthica seeds. Most farmers own less than 3 ha of land, which is too small to allow effective crop rotation in controlling S. hermonthica. Previously, in Nigeria, $79 \%$ of farmers confirmed using hand weeding in S. hermonthica management, while only the remainder used hoeing and inorganic fertiliser application [17]. Inorganic fertilisers enhances pearl millet growth and development and its competitive ability against Striga infestation. Although these methods have been encouraged for many years, crop losses are still high due to a wide host range for S. hermonthica and the persistence of its seed in the soil for long periods [40]. Furthermore, these methods have many limitations, including being labour intensive and not managing underground S. hermonthica infestation of pearl millet roots before the parasitic plants emerge. Therefore, integrating breeding for S. hermonthica host resistance with other control measures, such as biological control, may offer a more viable solution to control S. hermonthica infestation [40]. 


\section{Conclusions}

Pearl millet is an important cereal crop adapted to arid and semi-arid environments. In Burkina Faso, pearl millet production is primarily constrained by S. hermonthica infestation, which is estimated to cause up to $80 \%$ yield losses. Many respondent farmers $(68 \%)$ used local varieties with low yield potential, which are also highly susceptible to $S$. hermonthica infestation. Hand weeding and hoeing were the most commonly used methods to control S. hermonthica, although they are not very effective. The farmers lack resources such as labour, inorganic fertilizer, and finance to implement more effective strategies against $\mathrm{S}$. hermonthica and boost agricultural productivity. Therefore, an integrated management approach, which would involve breeding for S. hermonthica host resistance combined with other control measures, may offer a better option for managing S. hermonthica infestation in Burkina Faso. It is also recommended that variety design and development for $S$. hermonthica resistance be coupled with agricultural development such as improved extension services, increased access to information, access to micro-finance, and developing functional agro-input systems. The provision of an enabling environment would draw maximum benefits from improved varieties of pearl millet. Local farmers perceived that landrace varieties have good eating quality and adaptation to adverse effects.

Author Contributions: A.R.: Methodology, data analysis, and Writing of the manuscript draft. H.S.: Recourses, Supervision, writing conceptualization, review, and editing. M.L.: Review and editing. I.D.: Coordinated data collection, review and editing. P.G.: Review and editing. I.M.: Writing, review and editing. E.M.: Writing, review and editing. A.I.T.S.: Review and editing. All authors have read and agreed to the published version of the manuscript.

Funding: The research activities were funded by the International Crops Research Institute for the Semi-Arid Tropics (ICRISAT)) through the 'Harnessing Opportunities for Productivity Enhancement (HOPE II) for Sorghum and Millets in Sub-Saharan Africa' project (OPP1198373), funded by the Bill \& Melinda Gates Foundation (BMGF).

Institutional Review Board Statement: Not applicable.

Informed Consent Statement: Not applicable.

Data Availability Statement: Not applicable.

Conflicts of Interest: The authors declare no conflict of interest. The authors declare that they have no competing interests.

\section{References}

1. Rao Venkata, N.; Rao, K.; Gupta, S.; Mazvimavi, K.; Kumara Charyulu, D.; Nagaraj, N.; Singh, R.; Singh, S.; Singh, S. Impact of ICRISAT Pearl Millet Hybrid Parents Research Consortium (PMHPRC) on the Livelihoods of Farmers in India; Research Report No 75; ICRISAT: Patancheru, India, 2018.

2. Shah, I.A.; Shah, S.; Zahir, S.; Saeedur, R.; Muhammad, N. Characterization of pearl millet germplasm for various morphological and fodder yield parameters. Pak. J. Bot. 2012, 44, 273-279.

3. FAOSTAT. FAOSTAT Online Database 2020; FAO: Rome, Italy, 2020.

4. Drabo, I.; Zangre, R.G.; Danquah, E.Y.; Ofori, K.; Witcombe, J.R.; Hash, C.T. Identifying famers' preferences and constraints to Pearl Millet productionin the Sahel and North-Sudan zones of Burkina Faso. Exp. Agric. 2019, 55, 765-775. [CrossRef]

5. Bationo, A.; Ntare, B.R. Rotation and nitrogen fertiliser effects on pearl millet, cowpea, and groundnut yield and soil chemical properties in a sandy soil in the semi-arid tropics, West Africa. J. Agric. Sci. 2000, 134, 277-284. [CrossRef]

6. $\quad$ Emechebe, A.M.; Ellis-Jones, J.; Schulz, S.; Chikoye, D.; Douthwaite, B.; Kureh, I.; Tarawali, G.; Hussaini, M.A.; Kormawa, P.; Sanni, A. Farmers'perception of the Striga problem and its control in northern Nigeria. Exp. Agric. 2004, 40, 215-232. [CrossRef]

7. Boussim, I.J.; Yonli, D.; Guinko, S.; Sallé, G. Etat d'infestation, connaissance endogène et approche systématique des espèces du genre Striga au Burkina Faso. Int. J. Biol. Chem. Sci. 2011, 5, 1374-1386. [CrossRef]

8. Zombré, P.N.; Nikiéma, S. Importance et effet de Striga hermontheca (Del.) Benth sur la production du sorgho en zone Nord Soudanienne du Burkina Faso: Cas de Linonghin. Rev. Réseau L'amélioration Product. Agric. Milieu Arid. 1992, 4, 103-112.

9. Traoré, H.; Yonli, D. Striga et autres adventices: Perception paysanne et inventaire des méthodes endogènes de lutte dans l'Est du Burkina Faso. Sci. Nat. Agron. 2001, 25, 46-59.

10. Mrema, E.; Shimelis, H.; Laing, M.; Bucheyeki, T. Screening of sorghum genotypes for resistance to Striga hermonthica and S. asiatica and compatibility with Fusarium oxysporum f. sp. strigae. Acta Agric. Scand. Sect. B Soil Plant Sci. 2017, 67, 395-404. 
11. Chambers, R. Rural Apprasial: Rapid, Relaxed and Participatory; IDS Discussion Paper 311; IDS1992; Institute of Development Studies: Brighton, UK, 1992.

12. Negash, Z.; Nega, F.; Gebregziabher, K.; Ejigu, A.; Berhanu, M.; Nyssen, J.N.; Babulo, B.; Deckers, J.; Tollens, E. Manual for Participatory Rural Appraisal (PRA) in Villages of Tigray; Faculty of Business and Economics, Mekelle University: Mekelle, Ethiopia, 2006.

13. FAO. Participatory Rural Appraisal (PRA) Manual; FAO: Rome, Italy, 2009; p. 56.

14. Chambers, R. Participatory rural appraisal (PRA): Challenges, potentials and paradigm. World Dev. 1994, 22, 1437-1454. [CrossRef]

15. DeVries, J.; Toenniessen, G.H. Securing the Harvest: Biotechnology, Breeding, and Seed Systems for African Crops; CABI: Wallingford, UK, 2001.

16. Omanya, G.; Weltzien, E.; Sogodogo, D.; Sanogo, M.; Hanssens, N.; Guero, Y.; Zangré, R. Participatory varietal selection with improved pearl millet in West Africa. Exp. Agric. 2007, 43, 5-19. [CrossRef]

17. Dawud, M.A.; Angarawai, I.I.; Tongoona, P.B.; Ofori, K.; Eleblu, J.S.; Ifie, B. Farmers' Production Constraints, Knowledge of Striga and Preferred Traits of Pearl Millet in Jigawa State, Nigeria. Glob. J. Sci. Front. Res. D Agric. Vet. 2017, 17, 1-7.

18. Pieyns, S.A. Amélioration de la Connaissance et de la Gestion des Eaux au Burkina Faso; World Bank: Washington, DC, USA, $2017 ;$ p. 104.

19. Traoré, K.; Toé, A. Capitalisation des Initiatives sur les Bonnes Pratiques Agricoles au Burkina Faso; MAHRH/DVRD: Ouagadougou, Burkina Faso, 2008.

20. MAAH. Annuaire des Statistiques Agricoles 2019 (MAAH, Burkina Faso); DGESS: Ouagadougou, Burkina Faso, $2020 ;$ p. 434.

21. FAOSTAT. FAOSTAT Online Database 2021; FAO: Rome, Italy, 2021.

22. Ceccarelli, S.; Guimarães, E.P.; Weltzien, E. Plant Breeding and Farmer Participation; Food and Agriculture Organization of the United Nations: Rome, Italy, 2009; p. 685.

23. BBerchie, J.; Dapaah, H.A.; Dankyi, A.; Plahar, W.; Quartey, F.N.; Haleegoah, J.; Agyei, J.A.; Addo, J. Practices and constraints in Bambara groundnuts production, marketing and consumption in the Brong Ahafo and Upper-East Regions of Ghana. J. Agron. 2010, 9, 111-118. [CrossRef]

24. Ajeigbe, H.A.; Goodrich, C.G.; Ntare, B.R.; Weltzien, E.; Ndjeunga, J. Involving women in research for economic growth through agricultural technologies and practices: ICRISAT's initiatives in sub-Saharan Africa. Secheresse 2013, 24, 359-366. [CrossRef]

25. Ellis, F. Peasant Economics: Farm Households in Agrarian Development; Cambridge University Press: Cambridge, UK, 1993 ; Volume 23.

26. Mrema, E.; Shimelis, H.; Laing, M.; Bucheyeki, T. Farmers' perceptions of sorghum production constraints and Striga control practices in semi-arid areas of Tanzania. Int. J. Pest Manag. 2016, 63, 146-156. [CrossRef]

27. Fonta, C.L.; Yameogo, T.B.; Tinto, H.; Van Huysen, T.; Natama, H.M.; Compaore, A.; Fonta, W.M. Decomposing multidimensional child poverty and its drivers in the Mouhoun region of Burkina Faso, West Africa. BMC Public Health 2020, 20, 149. [CrossRef] [PubMed]

28. Mwangi, E.; Patrick, E. Land Rights for African Development: From Knowledge to Action; CGIAR CAPRi: Washington, DC, USA, 2006.

29. Rahman, M.Z.; Yamao, M. Farmers' Attitudes towards Participatory Resource Management for Sustainable Farming Development: A Study from Bangladesh; Hiroshima University: Hiroshima, Japan, 2006; pp. 632-639.

30. PNDES. Plan National de Développement Economique et Social (PNDES) 2016-2020; PNDES: Burkina Faso, South Africa, 2016 ; p. 97.

31. Sorgho, Z. Économie Agricole du Burkina Faso: Un Potentiel de Développement; Éditions Baudelaire: Lyon, France, $2010 ;$ p. 163.

32. Boubacar, I. The Effects of Drought on Crop Yields and Yield Variability in Sahel; University of Wisconsin: Stout, WI, USA, 2010.

33. Lubadde, G.; Tongoona, P.; Derera, J.; Sibiya, J. Production determinants of the pearl millet cropping system in Uganda and implications to productivity. J. Agric. Sci. 2016, 8, 97-111. [CrossRef]

34. Bishaw, Z. Wheat and Barley seed Systems in Ethiopia and Syria. Ph.D. Thesis, Wageningen University, Wageningen, The Netherlands, 2004; p. 383.

35. Nagayets, O. Small farms: Current status and key trends. In Proceedings of the Research Workshop Wye College, Wye, UK, 26-29 June 2005; p. 14.

36. Fisher, M.; Kandiwa, V. Can agricultural input subsidies reduce the gender gap in modern maize adoption? Evidence from Malawi. Food Policy 2014, 45, 101-111. [CrossRef]

37. Yoneyama, K.; Awad, A.A.; Xie, X.; Takeuchi, Y. Strigolactones as germination stimulants for root parasitic plants. Plant Cell Physiol. 2010, 51, 1095-1103. [CrossRef] [PubMed]

38. Ouedraogo, N.; Sanou, J.; Kam, H.; Traore, H.; Adam, M.; Gracen, V.; Danquah, E.Y. Farmers' perception on impact of drought and their preference for sorghum cultivars in Burkina Faso. Agric. Sci. Res. J. 2017, 7, 277-284.

39. Ghimire, R.; Huang, W.-C.; Shrestha, R.B. Factors affecting adoption of improved rice varieties among rural farm households in Central Nepal. Rice Sci. 2015, 22, 35-43. [CrossRef]

40. Cotter, M.; de la Pena-Lavander, R.; Sauerborn, J. Understanding the present distribution of the parasitic weed Striga hermonthica and predicting its potential future geographic distribution in the light of climate change. In Proceedings of the 25th German Conference on Weed Biology and Weed Control, Braunschweig, Germany, 13-15 March 2012; pp. 630-636. 